\title{
THE PHYTOPLANKTON BIOTA VARIATION ON THE TIMIȘ RIVER ACCORDING TO THE CHEMISTRY AND HYDROLOGY OF THE WATER COURSE
}

\author{
Hanelore MUNTEAN *, Iuliana DOBAI *, Cătălin MILOTIN * and Cristina GROZA * \\ * Banat River Basin Administration, Mihai Viteazul St. 32, Timişoara, Timiş County, RO-300223, \\ hane_elena@yahoo.com, iulianna.dobai@yahoo.com,_catalin_rowater@yahoo.com, \\ grozacris@yahoo.com
}

DOI: $10.2478 /$ trser-2013-0033.

KEYWORDS: phytobentos, phytoplankton, variation, integrated approach.

\begin{abstract}
The Timiş River is the biggest tributary of the Banat catchment area. It springs at an elevation of $1145 \mathrm{~m}$, under Piatra Goznei peak. Due to the fact that it crosses several relief forms, its hydrology, chemistry and biological characteristics are modified in consequence.

The chemical and biological analysis of the water course and their correlation with hydrological data displayed evidence of the interdependence of these factors. The phytoplankton composition and richness are directly influenced by river's chemistry and hydrology. In the mountain area, the flow and the speed of the watercourse are inducing a specific flora and fauna for the area. In the lower areas, the river hydrology triggers a change in the biological characteristics as the water chemistry changes. The mountain species are adapted to rocky substrata in order to resist high water velocity and pressure. In the lower areas they are replaced by lowland species adapted to larger yet slower flows.

The Timiş River is a watercourse that did not undergo major qualitative changes in terms of water quality.

RÉSUMÉ: La variation du phytoplancton dans la rivière de Timiș induite par l'hydrologie et la chimie de l'eau.

Le Timiș est le plus grand effluent du bassin hydrographique du Banat. Ses sources se trouvent à une altitude de $1145 \mathrm{~m}$ sous la cime de Piatra Goznei. L'hydrologie, la chimie et la biologie de la rivière changent le long de son tracé car la rivière traverse plusieurs types de relief.

Les résultats obtenus par l'analyse chimique de l'eau et de l'analyse du phytoplancton ont été corélés avec les données hydrologiques, mettant en evidence les relations d'interdépendence entre ces paramètres. La composition et l'abondance du phytoplancton sont directement influencées par la chimie de l'eau et pas l'hydrologie de la rivière. Dans la région de montagne, le débit et la vitesse de l'eau séléctionnent une flore et une faune spécifique. Dans les secteurs de plaine, l'hydrologie de la rivière change, tout comme la chimie de l'eau, ce qui engendre également un changement des caractéristiques de la flore planctonique. Les espèces de montagne sont adaptées à un substrat rocheux leur permettant de résister aux pressions dues à la vitesse de l'eau. Elles sont remplacées dans les secteurs infèrieures par des espèces de la zone de plaine, étant donné que le débit est plus grand et la vitesse de l'eau plus faible.

La rivière de Timiș est un cours d'eau qui n'a pas subit des changements majeurs de la qualité de l'eau.
\end{abstract}


REZUMAT: Variaţia biotei fitoplanctonice din râul Timiş în funcţie de chimia şi hidrologia cursului de apă.

Râul Timiș este cel mai mare drenant din spațiul hidrografic Banat. Izvorăște de la o altitudine de 1145 m, de sub vârful Piatra Goznei. Datorită faptului că traversează mai multe forme de relief suferă modificări ale hidrologiei, chimiei și biologiei.

Prin analiza chimică și biologică, pe segmentul de fitoplancton, a cursului de apă și prin corelarea cu datele hidrologice s-au evidențiat relațiile de interdependență dintre ele. Compoziția și abundența fitoplanctonului sunt direct influențate de chimia apei și de hidrologia râului. În zona de munte, debitul și viteza apei imprimă o floră şi o faună specifică acestei zone. Spre zona de câmpie hidrologia râului se modifică, chimia apei de asemenea, ceea ce determină și o schimbare a caracteristicilor florei planctonice. Speciile de munte sunt adaptate la substrat pietros pentru a rezista la presiunile datorate vitezei apei. Acestea sunt înlocuite în sectoarele inferioare cu speciile din zona de câmpie, unde debitul este mai mare și viteza apei mai mică.

Râul Timiș este un curs de apă care nu a suferit modificări calitative majore ale calității apei.

\section{INTRODUCTION}

Human activity often engenders the water pollution. The water is necessary in order to sustain life, but it also has the role to collect and transport different kinds of residues.

The water pollution determines its qualitative depreciation downstream and has negative effects on human health and aquatic ecosystems, thus further implying the reduction of the effective use as well as a larger competition for "proper" water. The protection of terrestrial and aquatic ecosystems plays an important role in the development of different processes in nature. The full awareness of the status, activity and even more of the evolution of a water course cannot be achieved without data on all composing parameters: biological, chemical and hydrological.

The integrated approach in the river analysis is very important considering the interdependence relations between biological, chemical and hydrological factors acting together or separately in the processes taking place in water.

\section{MATERIAL AND METHODS}

The samples for the chemical analysis were taken according to the standards in force, according to the provisions of DCA 2000/60/EC.

The chemical data were obtained from the tests performed on water samples by the Banat Catchment Area Water Resource Administration - the Water Quality Laboratory of Timișoara. The standards used for the analysis of the monitored chemical parameters are:

-oxygen variation monitoring:

- SR EN 25813/2000 - Water quality. Dissolved oxygen dosage. Iodometry method.

- SR EN 1899-1/2003 - Water quality. Biochemical oxygen use determination after " $n$ " days. Dilution and allylthiourea adding method.

- SR EN 1899-2/2002 - Water quality. Biochemical oxygen use determination after " $n$ " days. Diluted samples method.

-nutrients monitoring:

- SR EN ISO 6878/2005- Water quality. Phosphorus determination. Spectrophotometric method using ammonia molibdate.

- SR ISO 10048/2001 - Water quality. Nitrogen content determination. Catalytic mineralisation after reduction with Devarda alloy. 
- SR ISO 7890-1/1998 - Water quality. Nitrates content determination. Spectrometric method with 2.6 dimethyl-phenol.

- SR ISO 7150-1-2001 - Water quality. Ammonia content determination Part 1 - Manual spectrometric method

- SR EN 26777/C91/2006 - Water quality. Nitrite content determination - Molecular absorption spectrometric method.

\section{- For macrozoobenthos samples}

The macrozoobenthos investigation from the river substrata requires various sampling methods (according to standards in force) in order to establish the dominant biotope. The macrozoobenthos samples contain aquatic animals most of which are visible by the naked eye. These are sampled according to the characteristics of the riverbed with different instruments: scraper and hoop net. Afterwards the sample is washed and the sampled individuals are identified at species level using the dedicated literature using a stereomicroscope and classic microscope.

- Phytoplankton samples were taken and treated according to DRAFT $\mathrm{N}$ 109/2008/04/15-Draft proposal for "Water Quality - Guidance on quantitative and qualitative sampling of phytoplankton from inland waters".

- Standard SR EN 15204 - Guidelines for routine analysis of phytoplankton composition and abundance using the reverse microscopy (Uthermol method).

-The phytobentos was sampled according to SR EN 13945:2006 Water quality. Guidelines for the routine treatment and pre-treatment of the benthonic diatoms of rivers and according to the SR EN 14407 Standard for river benthic diatom sample identification, numbering and their interpretation.

\section{RESULTS AND DISCUSSIONS}

The sustainable management of the water sources must be made is an integrated manner at qualitative and quantitative levels for the entire catchment area. The integrated approach regarding qualitative and quantitative as well as of the hydrological conditions contribute for a better environmental protection. The surface waters and protected areas monitoring is performed as follows:

- surface water monitoring consists of the monitoring of the volume and flow level as well as ecological state, chemical state and ecological potential;

- for water analysis and monitoring, technical specifications and standards methods according to the procedure in force are used (Carabeț, 2009).

The Timiș River is the biggest draining effluent of the Banat catchment area. It collects the waters of the most important relief units of Banat, which register at the Serbian frontier an average altitude of $390 \mathrm{~m}$ of the catchment area. The main stream of the Timis River follows the Caransebeş-Mehadia couloir and it is the main collector of a large number of rivers of the Ţarcu-Godeanu Mountains; as well as of the Semenic and Poiana Rusca Mountain ranges (Nagy, 2004).

For the present study, the river sections surveyed in 2012 on the Timiș River are: upstream Teregova, upstream Sadova Veche, upstream Potoc, upstream Lugoj, upstream Hitiaș and upstream Șag, village of Grăniceri. 
The Timiș River suffers qualitative and quantitative modifications of the water resources, one of the causes being that it crosses various types of geological forms, while the second cause is the increase of water use from upstream sectors towards the downstream sectors.

The water flow and speed have an essential role for the aquatic activity and evolution. The water chemical composition as well as the aquatic environment diversity depend on these hydrological parameters.

The Timiș River hydrological characteristics in 2012 are presented below.

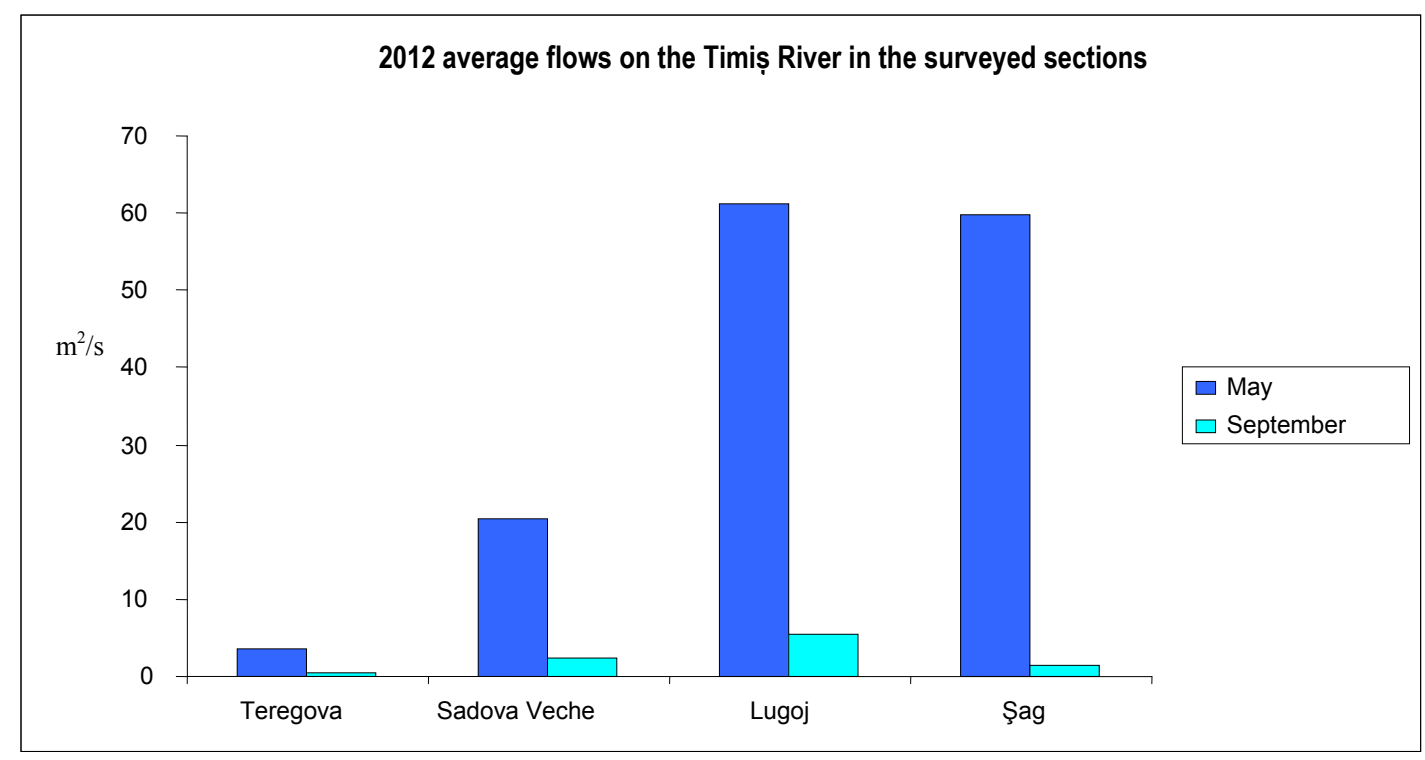

Figure 1: The Timiș River water flow in the surveyed sections.

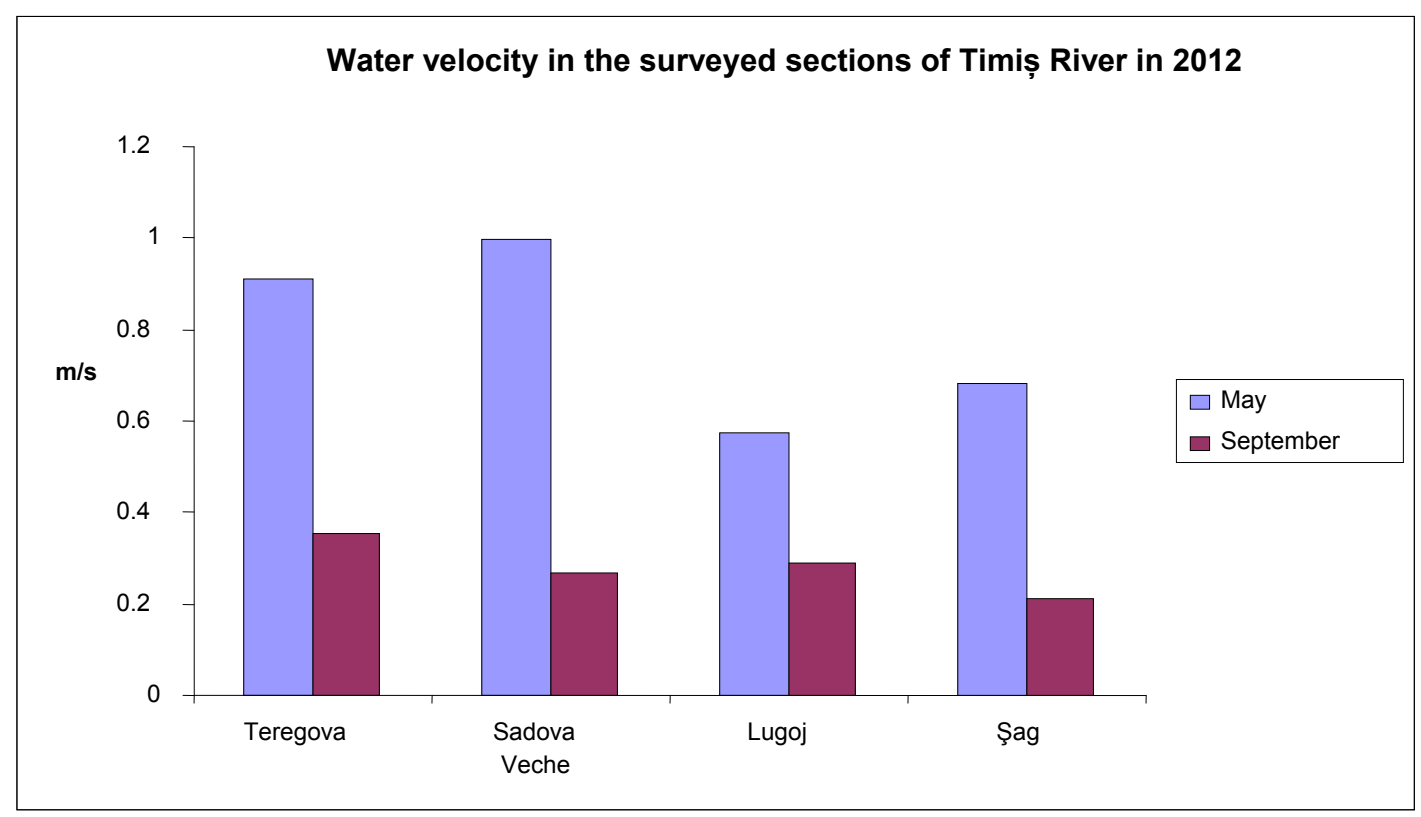

Figure 2: Water speed in the surveyed sections of Timiș River in 2012. 
The Timiș River water flow increases from upstream towards downstream (Fig. 1). The largest values are recorded for the month of May, significantly decreasing in September. On the contrary, the speed decreases downstream. As for the flows, the largest water speeds are registered in the month of May and they decrease significantly in September (Fig. 2).

The snow melt and the spring precipitations are at the origin of the increase of these parameters, while the high temperatures and the summer drought led to their significant decrease in September.

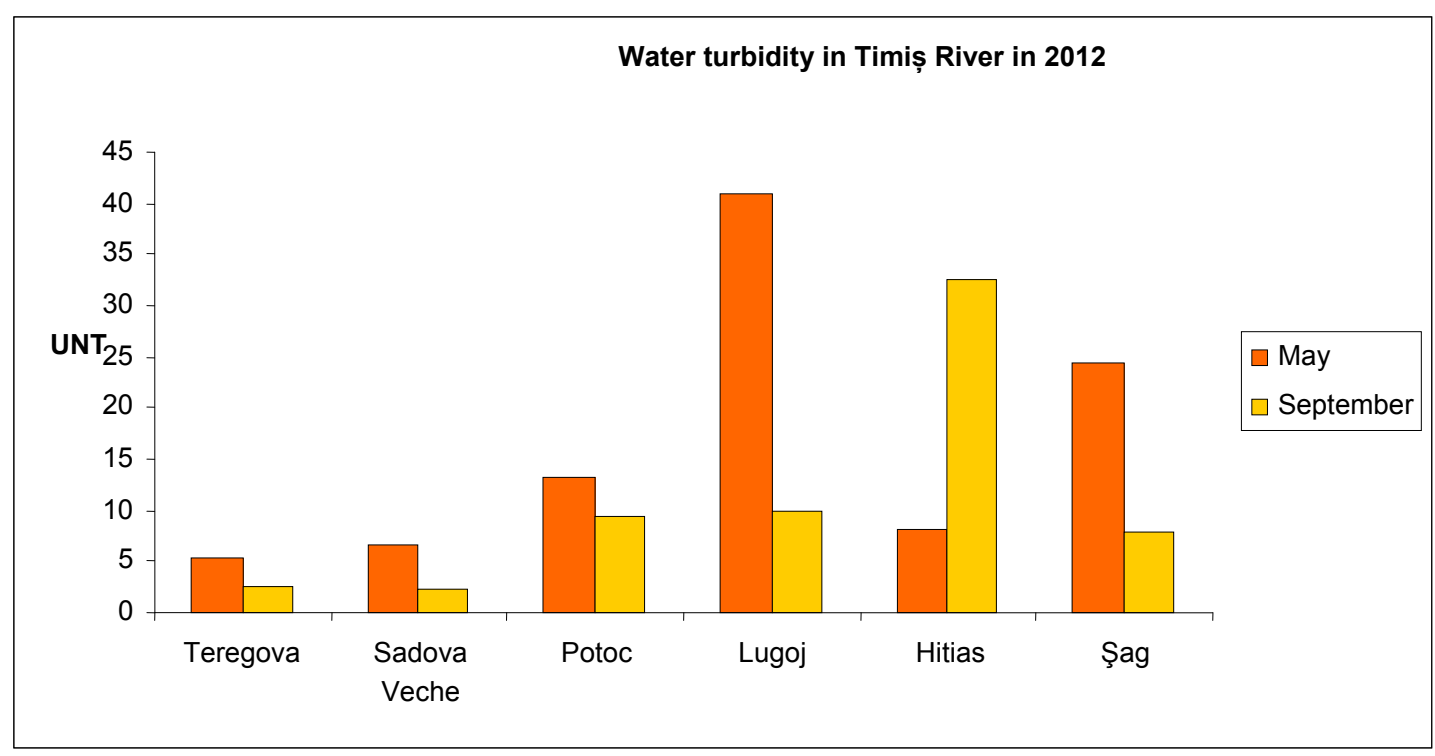

Figure 3: The variation of water turbidity in the Timiș River in the surveyed sections (2012).

A very important parameter directly influencing the aquatic organism's development is turbidity. The water turbidity results in the solid particles fragmentation and floating as well as in the development of planktonic organisms and microorganisms. Turbidity blocks the light penetration in the water layer, thus inhibiting photosynthesis and inducing a negative effect on fish and macrozoobenthos, with the additional effect of the silt depositing on the bottom (Buta and Pişota, 1975; Popa, 1997).

High turbidity can even stop photosynthesis in a short period of time and results in a decrease of the dissolved oxygen concentration. The suspended matter may carry toxic substances or too large quantities of organic substances and by sedimentation can suffocate benthonic organisms.

During the month of May the turbidity is high in all surveyed sections due to the high water speed carrying organic matter in the entire water layer. Once the water speed drops in September, the turbidity is also very low compared to May data (Fig. 3).

The Timiș River in May is chemically characterized as follows. 


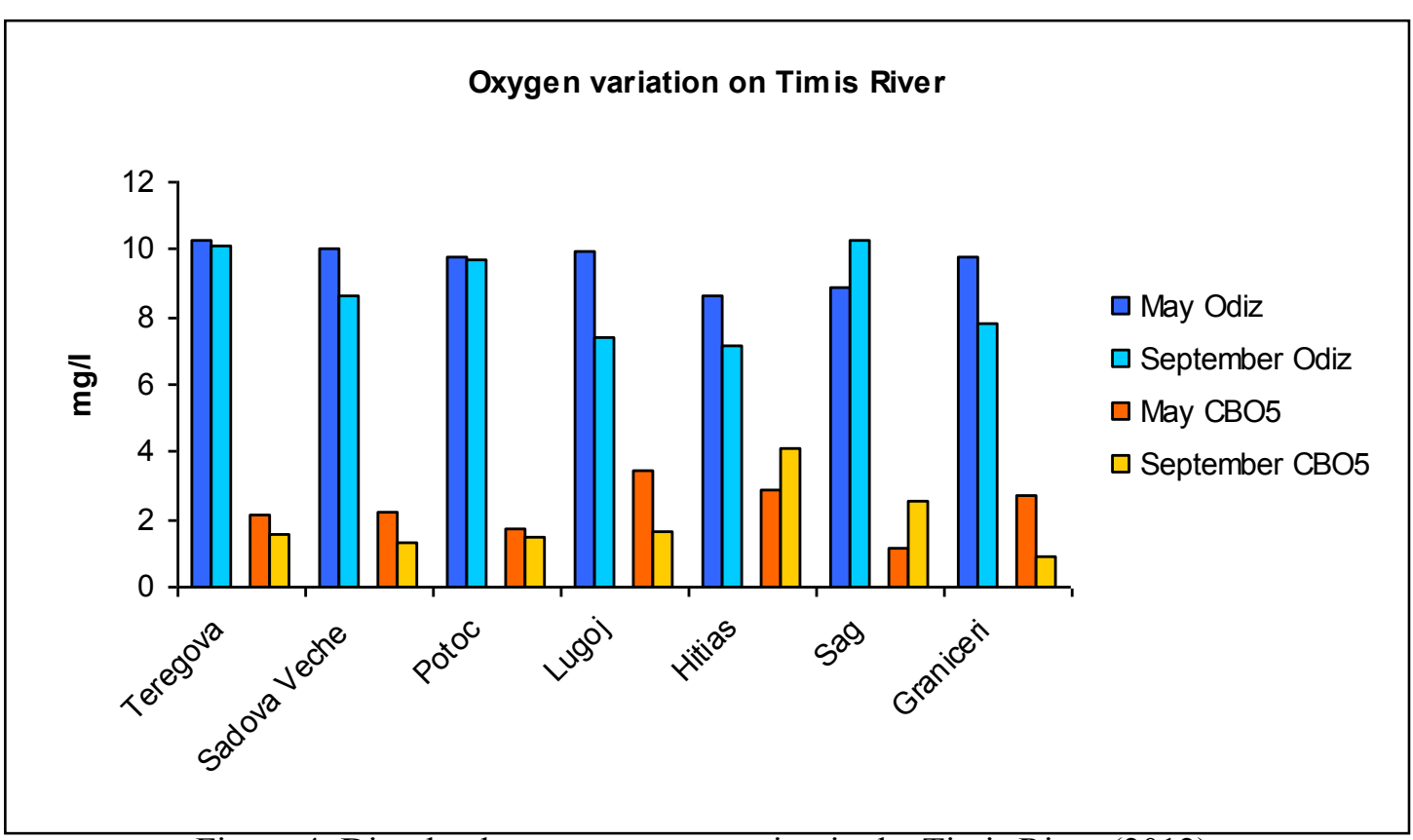

Figure 4: Dissolved oxygen concentration in the Timiş River (2012).

The dissolved oxygen concentration consists, for the surveyed sections of the Timis River, with a good and very good quality class, and is corroborated with the classification based on the biochemical oxygen consumption. The highest value for the later corresponds to the Lugoj section in May and to Hitiaș section in September.

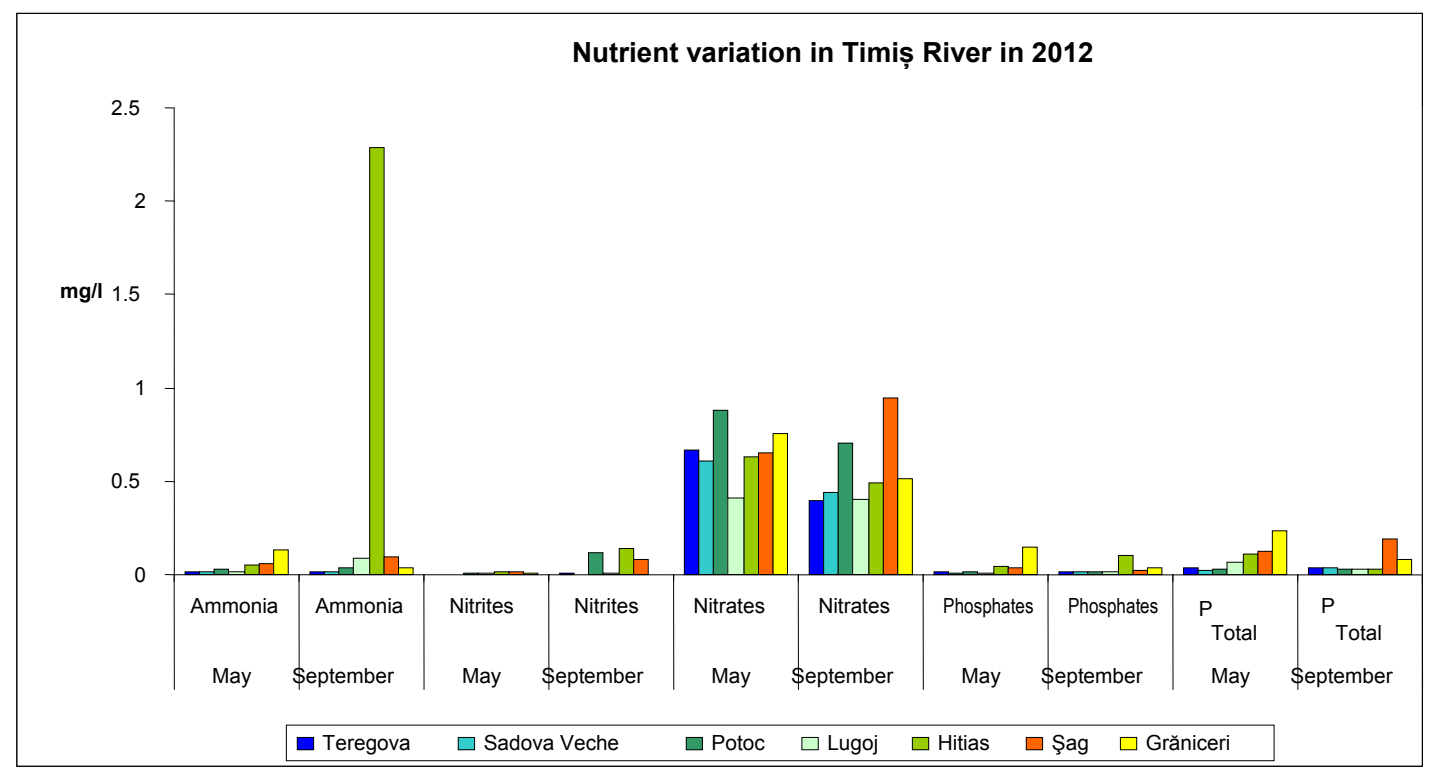

Figure 5: The nutrient variation in Timiș River (P Total - total Phosphorus). 
The ammonia has registered the smallest values during the month of May, the water speed and the large flow led to its self-cleaning; but in September the ammonia concentration increases in all sections, especially in the Potoc section. The nitrites are present in very small quantities for the month of May and increase significantly in September.

The largest values of the nitrates concentration are found in the samples of the Potoc section in May and the Sag section in September. The variations of phosphate and total phosphorus concentrations are small. Larger quantities are found in the Șag and Grăniceri sections in both surveyed periods.

The biological parameters, along the Timiș River, vary greatly due to the changes in the hydromorphology and the chemistry of the watercourse.

At the river's springs, in the Teregova section, the macrozoobenthos species registering the highest density in both seasons are: Ancylus fluviatillis, Gammarus roeseli and Heptagenia sulphurea, but the presence of the oligo-saprobial species Epeorus sylvicola, Perla marginata and Sericostoma personatum is the parameter showing that the water is very clean in this section.

The phytobentos, in this section, for the month of May, is composed mainly of diatoms, dominated by the oligo- $\beta$-mezosaprobial species: Achnanthes minutissima, Cymbella ventricosa, Diatoma elongatum, Stephanodiscus astrea, Tabellaria fenestrata and oligosaprobial species Ceratoneis arcus. Their density was of 425 individuals/sample. In September Tabellaria fenestrata is no longer found in this section, the rest of the species persisting, and their density in one sample being of 417 individuals/sample.

In the Sadova Veche section persists the Potoc fauna, the water quality is stationary. The phytobentos was surveyed in this section too, its density registering 412 individuals/sample, the dominant species are oligo-saprobial, $\beta$-mezosaprobial, as well as $\alpha$ saprobial: Cocconeis pediculus, Cocconeis placentula, Cymbella ventricosa, Diatoma elongatum, Melosira granulata, Meridion circulare, Navicula cryptocephala, Rhoicosphenia curvata.

The section upstream of Potoc is characterized by the present Ancylus fluviatillis, Gammarus roeselli, Hydropsyche pellucidula, Heptogenia sulphurea, Seratella ignita, Glossiphonia complanata. In this section the oligo-saprobe species are missing, being replaced by $\alpha$-saprobial species, and the water quality is depreciated.

Due to the riverbed widening and the decrease of the water speed, we monitor the phytoplankton in this section:

- in May, for a density of 1622 algal objects $/ \mathrm{ml}$ the dominant species are: Cymbella ventricosa, Diatome elongatum, Diatoma vulgaris, Gomphonema olivaceum;

- in September the phytoplankton density reaches 1689 algal objects $/ \mathrm{ml}$, and the dominant species are: Achnanthes minutissima, Diatoma vulgaris, Fragilaria capucina, Gomphonema constrictum and Navicula rhynchocephala. Didymosphenia geminata, was identified here, after the first identification in the Prut River, then the Bistriţa River and in the Bicaz River reservoir. Recent data shows that Didymosphenia geminata appears suddenly in the year 2000 and it is profuse in many rivers of Transylvania, such as: Someşul Rece, Someşul Cald, Someşul Mic, Crişul Repede, Valea Drăganului, Arieş River, Mureş River and Olt River. The present situation in Romania, characterized by the lack of monitoring programs for the algal communities of many aquatic ecosystems, is making the evaluation of this species impact on the already established communities nearly impossible. 
The results of several authors of Europe, Asia, New Zeeland and North America regarding the invasive behaviour of $D$. geminata show that its massive presence affects the habitat of the benthonic macro invertebrates and fish. A decrease of the abundance and richness of some invertebrate groups was noticed, such as the case of Chyronomids or Oligochaetae that feed on algae, but cannot consume Didimosphenia geminate (Momeu, 2009).

This species reproduction at large scale leads to "algal blooms" and impacts the dissolved oxygen concentration not only during the vegetation period but also during the fall and winter when organic matter is decomposed, due to the occurrence of the mucilaginous peduncles. Didymosphenia geminata affects humans as well, inducing eye irritations.

The following surveyed section on the Timiș River is the one upstream of Lugoj where the dominant species are: Ecdyonurus venosus, Ephmerella ignita, Micronecta sp., and Hydopsyche angustipennis. The clean water indicating species present in this section are: Haplotaxis gordioides, Habroleptoides confusa and Ecdyonurus venosus. The water quality in the Lugoj section is good for the month of May. In September the dominant species are Tanypodinaelae, Calopterix virgo and Baetis rhodani.

The phytoplankton density in the Lugoj section is of 1060 algal objects/ml in May. The following species dominate: Cymbella cistula, Cymbella ventricosa, Diatoma vulgaris and Cocconeis pediculus. Didymosphenia geminata is also present in this section. In September, phytoplankton density is of 1066 algal objects $/ \mathrm{ml}$. During this period, the specific richness increases significantly, the following species being dominant: Diatoma vulgaris, Cyclotella meneghiniana, Cymbella tumida, Navicula capitatoradiata, Navicula minuta, Ulnaria ulna, Nitzschia palea and Cymbella ventricosa. Other species present during this period are: Anomoeoneis sphaerophora, Ulnaria oxyrhynchus, Navicula pygmaea, Cyclotella stelligera, Cymbella cymbiformis, Didymosphenia geminata and Navicula cuspidata var. heribaudii.

The middle course of the river is characterized by the significant riverbed widening, and the water speed decreases step by step. Thus the Hitias section of this river sector is characterized by the presence of the following species Piscicola geometra, Lithogliphus naticoides, Procloeon bifidum, Potamanhus luteus, Caenis macrura, Hydroptila sp., Helycomiza ustulata, Micronecta sp., Tipula lunulata, Simulium sp., Hydropsyche angustipennis meaning that the water has good quality.

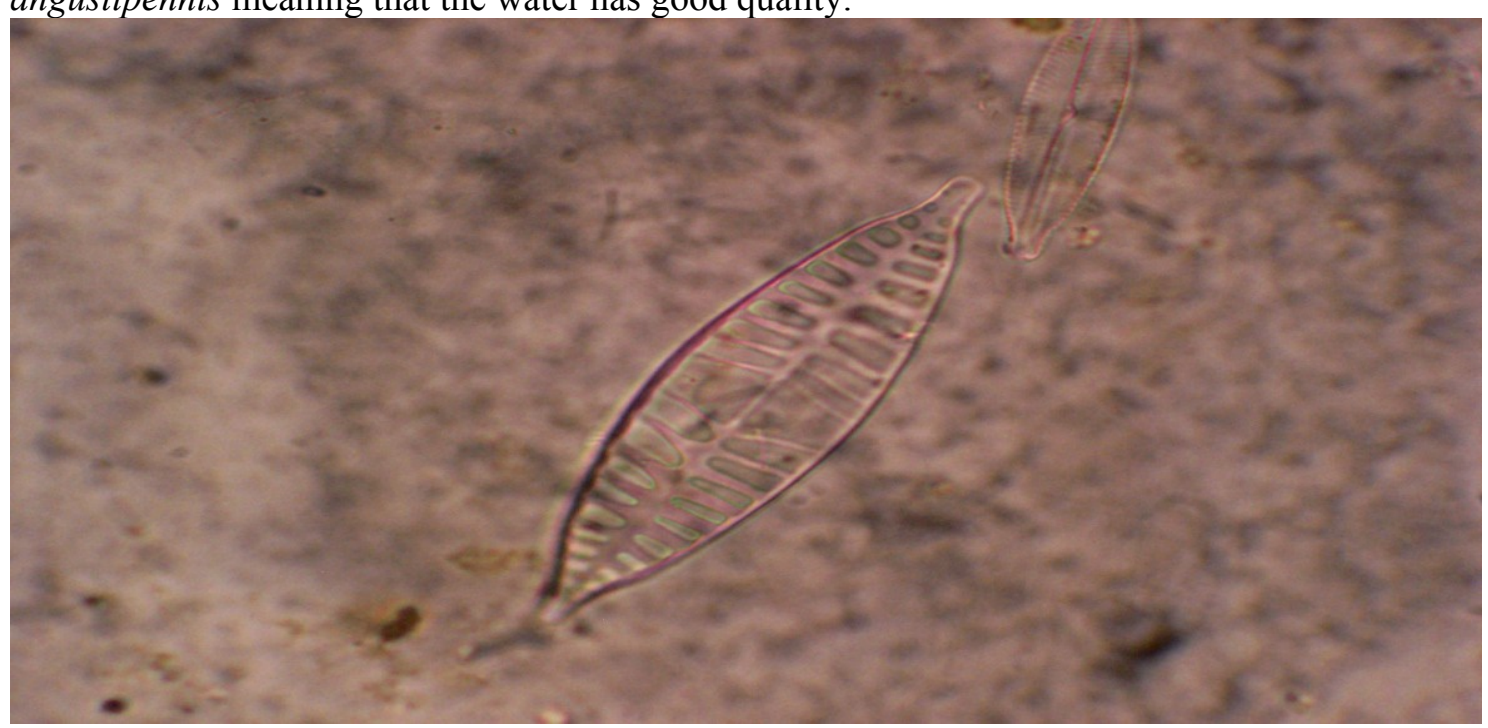

Figure 6: Navicula cuspidata var. Heribaudii. 
The Hitiaș section went through major riverbed modifications due to excavation works in the area. In these conditions the macrozoobenthos and phytoplankton species richness suffered various changes and their diversity is low. The phytoplankton samples analyzed in this section during the month of May contained species such as: Ulnaria ulna, Navicula radiosa, Diatoma mesodon, Diatoma vulgaris, Cocconeis pediculus, Synedra acus, Cyclotella meneghiniana, Fragilaria crotonensis, Gomphonema constrictum, Hantzschia amphyoxis and Didymosphenia geminata.

In September the species number increases significantly. There are species that were not accounted for in May but that are present in September: Navicula pygmaea, Caloneis silicula, Navicula bacillum, Pinnularia microstauron, Gyrosigma scalproides, Neidium affine, Cyclotella radiosa, Cymbella cuspidata, Nitzschia sigma, Pinnularia major, Stauroneis smithii and Rhoicosphenia abbreviata.

The Grăniceri section is situated at the Serbian border in a lowland region. The waterbed is wide, the water course is smooth. The macrozoobenthos is formed of the following species: Unio pictorum, Haplotaxix gordioides, Gammarus fossarum, Procloeon bifidum, Ecdyonurus dispar, Calopterix virgo, Lestes viridis, Ischnura elegans, Limnephilus lunatus, Limnephilus affinis, Dytiscus marginalis, Simulium sp. and Tanypus sp. The largest density have the species Haplotaxix gordioides, Simulium sp. and Tanypus sp.

The phytoplankton composition has a larger number of green algae compared to the other surveyed sections where these algae were almost inexistent: Scenedesmus opoliensis, Ankistrodesmus falcatus, Scenedesmus quadricauda. Asterionella formosa is also present, even though it is a species occurring mostly in stagnant waters, lakes etc. In September the number and the density of the species are very low. Alfa saprobial species appear: Navicula rhynchocephala, Stephanodiscus hantzschii, Cyclotella meneghiniana. The green algae are missing.

\section{CONCLUSIONS}

The hydrology of the watercourse of the Timiș River is normal, the slope decreases from the springs to the plain area determining a variation of the chemistry and of the biota. There are no major pressures of water use on this course that might alter the water quality significantly.

The chemical characteristics in the upper course gives indication for a very good water quality. Step by step, the parameter values are modified due to the anthropogenic impact, but the water is still of good quality according to the standards.

Once the water speed and flow drop, some of the parameters have increased concentrations; for instance the ammonia in the Hitiaş section.

The biological parameters are influenced by the water flow, water speed, and chemistry. In May, during high water speed and flow, the biological parameters are modified; the diversity is lower as well as the individual density.

The macrozoobenthos diversity is constant from one campaign to the other. The discrepancies appear when mountain and plain regions are compared. In the mountain area Ancylus fluviatillis, Perla marginata and Sericostoma personatum are species which adapted to a large water speed and they are not present in the plain. In the Hitiaș, Șag and Grăniceri section, due to the riverbed widening and to the presence of sand and silt, Unio pictorum species occurs. 
The mountain area surveyed phytobentos registers, an approximate constant density of the individuals, both in the Teregova section and the Sadova Veche section. The species richness is similar.

In the Potoc, Lugoj, Hitiaș, Şag and Grăniceri sections, the phytoplankton was surveyed and analyzed, and the species Didymosphenia geminate (Momeu, 2009) was identified. It is an invasive species with potential to affect the macrozoobenthos, produce algal blooms, and affect humans. This species did not migrated upstream; the water speed is too big in the mountain area.

In September, the water speed and flow are very low, thus the number of the phytoplankton species increases and green algae appear.

In the Hitias section, the large amount of ammonia from this month does not affect the macrozoobenthos or the phytoplankton.

In the Lugoj section for the month of September the following species are identified: Navicula cuspidata var. Heribaudii (Fig. 6) and Anomoeoneis sphaerophora. The environmental conditions for the occurrence of these species are: relatively low water flow and speed, relatively high amounts of ammonia, very small amounts of phosphates and total phosphorus, nearly inexistent nitrites and quite large amounts of nitrates.

\section{REFERENCES}

1. Buta I. and Pisota I., 1975 - Hidrologie, Edit. Didactică și pedagogică București, 11-54. (in Romanian)

2. Carabeț A., 2009 - Monitoringul apelor, Facultatea Hidrotehnică, Timişoara, 695-699. (in Romanian)

3. Mălăcea I., 1969 - Biologia apelor impurificate, Edit. Academiei Române, București, 11-65. (in Romanian)

4. Momeu L., 2009 - Problems concerning the invasive species from continental aquatic ecosystems Case study: Didymosphenia geminata (Lyngb.), Schmidt, in Rakosy L. and Momeu L. (eds.) Neobiota din România, Presa Universitară Clujeană, 11-30.

5. Nagy C. and Şerban P., 2004 - Planul de Management al Spaţiului Hidrografic Banat, Administraţia Bazinală de Apă Banat, Timişoara, 1-75. (in Romanian)

6. Popa R., 1997 - Elemente de hidrodinamica râurilor, Edit. Didactică şi pedagogică, R. A, Bucureşti, 16-38. (in Romanian) 